\title{
POSSIBILITY OF THE DEVELOPMENT OF A SERBIAN PROTECTION SYSTEM AGAINST CHEMICAL ACCIDENTS
}

\author{
Dejan R. Indic, \\ University of Defense in Belgrade, Military Academy, \\ Belgrade
}

\author{
FIELD: Chemical Technology \\ ARTICLE TYPE: Professional Paper \\ Summary:
}

DOI: 10.5937/vojtehg1204133I

The paper presents a draft of a system model for responding in case of chemical accidents in accordance with the current legislation regarding the environment protection, the structure and elements of the existing response system in case of chemical accidents, other works dealing with the issue as well as the prospects planned by those responsible for the environmental protection. The paper discuss the possibilities of different institutions and agencies of the Republic of Serbia to engage in specialized methods of cooperation and protection against chemical hazards in accordance with Article $X$ of the Convention on the Prohibition of Chemical Weapons.

Key words: chemical accidents, response, protection.

\section{Introduction}

In accordance with the tendency towards European integrations,

the importance of environmental issues increases in Serbia (RS).

One of the important elements in complex environmental systems is the existence of response in case of chemical hazards. The Convention on the Prohibition of the Development, Production, Stockpiling of Chemical Weapons and on Their Destruction in the Republic of Serbia (former Yugoslavia) came into force in 2000 , after the ratification by the then-federal parliament [1].

Among other rights and obligations of Member States, the RS is fully prepared to work on improving its ability to cooperate in the protection against chemical weapons, in accordance with Article $X$ of the Convention on the Prohibition of Chemical Weapons. In accordance with the Constitution, the environmental protection issues are the responsibility of the State and the Ministry of Energy, Development and Environmental 
Protection. However, a part of the response system is the responsibility of other ministries such as the Ministry of Interior and the Ministry of Defence. For this reason, it would be necessary to establish a single government body to coordinate the involvement of ministries and their respective institutions [2].

In accordance with the latest developments in the field of protection from chemical hazards of any kind (use of chemical weapons, chemical accidents, terrorist acts on chemical industry facilities, etc.), the development of chemical protection in the RS should be carried out according to the following guidelines:

- Improvement of protection;

- Development of the state response to a crisis;

- Increasing the ability of the state to work on projects for protective purposes.

It would be, therefore, necessary to establish a single government body to coordinate the involvement of ministries and their respective institutions [2].

\section{Imploving measures of protection}

Improving protection measures should be carried out in several directions [3, 4]:

- Upgrading systems of legal regulation in the event of chemical (C) reaction accidents in line with European standards, norms and recommendations (APELL, UNEP, OECD, CEFIC, OPCW, etc.)

- Training and constant updating of databases on chemical production, storage and transport;

- Maintaining a database of toxic and hazardous chemicals;

- Constant upgrading of manuals and guidelines; and

- Providing adequate and modern equipment for teams to respond in case of chemical accidents.

\section{Development of the serbian crisis response}

The development of the RS system crisis response should be pursued through the following activities:

- Development of information systems (modernization and establishment of local information centers);

- Improving the management and cooperation at all levels of the entire system for crisis response;

- Increasing the effectiveness of risk assessment (software for the assessment of chemical hazard risks and consequences, prepared by local experts) [5]. 
- Development and equipping of regional mobile ecotoxicological laboratory (civilian and military).

- Constant upgrading of equipment and methodology for the treatment of victims of chemical hazards (The National Poison Control Center of the Military Medical Academy).

- Forming teams for the elimination of consequences of toxic effects and other hazardous substances (NBC service units, fire police unit, civil protection unit, etc.).

\section{Increase the ability of the RS to work on projects for protective purposes}

The ability of Serbia to work on projects for protective purposes is developed through the methods in the following areas:

- Sampling and analytical procedures for sample preparation;

- Instrumental analytical methods for the identification of highly toxic substances (HTS), their precursors and degradation products, as well as other toxic and harmful substances;

- Dynamic small-scale chamber for generating a constant concentration of gases and vapors for chemical detection and monitoring; - Analog apparatus for testing materials and colors on the effect of HTS and other toxic and harmful substances;

- Kinetic and analytical methods for determining the efficacy of decontamination using different HTS materials for the decontamination and methods (conductometry, potentiometry, pH-stat, etc.)

- Methods for complete characterization of equipment for nuclear, chemical and biological protection (protection time/penetration, sorption characteristics, resistance to thermal pulse of a nuclear explosion and burning napalm mixture, thermal characteristics, etc.)

- Application of modern instrumental methods (colorimetry, potentiometry, etc.).

\section{Purpose of the RS system to respond in situations of chemical hazards}

The purpose of the system to react in case of chemical hazards is to manage the risks of chemical accidents and other chemical hazards. As chemical accidents (caused by a human error, an error in a technical-technological process or a terrorist act) are the most widespread threat, hereafter the focus will be on the treatment of this segment. 
Risk management of chemical accidents includes measures and procedures for prevention, preparedness, response and rehabilitation of accidents to reduce the probability of their occurrence and possible consequences in order to create conditions under which the risk of accidents is acceptable. The activities of the system to respond in case of chemical accidents can be shown schematically in four stages - Figure 1 [6].

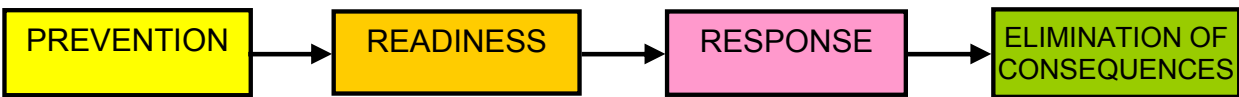

Figure 1 - The activities of the system to respond in case of chemical accidents Slika 1 - Aktivnosti sistema za reagovanje u slučaju hemijskog udesa ment:

The system response in case of chemical accidents to risk managecidents)

- Implementation of preventive measures (to minimize the risk of ac-

- Responding to an accident (injured and care for environmental protection),

- Remediation and restoration of affected areas (elimination of the consequences of chemical accidents).

\section{The activity of the government and relevant ministries}

In addition to prevention, the activities of the government and relevant ministries could be shown schematically as follows:

\begin{tabular}{|c|c|c|c|}
\hline $\begin{array}{l}\text { Prevention } \\
\text { - receive information } \\
\text { - check information } \\
\text { - collect details } \\
\text { - assessment } \\
\text { - put on alert }\end{array}$ & $\begin{array}{l}\text { Preparing } \\
\text { - decision } \\
\text { - staff } \\
\text { - equipment } \\
\text { - completion } \\
\text { - going to cort }\end{array}$ & $\begin{array}{l}\text { Response } \\
\text { - field work } \\
\text { - consultation with } \\
\text { experts }\end{array}$ & $\begin{array}{l}\text { Remediation } \\
\text { (removal of } \\
\text { consequences) } \\
\text { - rehabilitation plan } \\
\text { - field work } \\
\text { - report on an } \\
\text { accident }\end{array}$ \\
\hline
\end{tabular}

\section{Prevention}

- Information is received by:

* centers of information,

* endangered or neighboring businesses,

* municipal authorities,

* police operatives and the Army of Serbia,

* media and radio amateurs

* citizens. 
- Information is checked by:

* district inspectors and chiefs,

* the Republican Center for Intelligence.

- Collection and evaluation details are:

* data on the extent and type of ecological accidents, vulnerability of the population, flora and fauna, cultural and other goods,

* information on the involved forces and resources;

* data on whether the situation is under control and whether help is needed.

- Putting on alert means:

* put on alert the appropriate professional bodies, teams and experts.

Preparation includes:

* deciding which teams and equipment to engage and send to the field,

* Information (by the Republican Center for Intelligence) of the competent authorities and enterprises where the accident happened and what decision is made,

* communication of decisions made by professional organizations and experts who have chosen to go to sworn experts

* complete teams and equipment,

* leaving on the ground.

Response

Field work involves:

* taking measures to protect the population and the environment,

* maintaining a constant connection with the ministry and submitting periodical reports.

Consultations of experts that include:

* If necessary, requires commitment and other professional organizations and experts.

Remediation (removal of consequences of accidents)

Elimination of the consequences of accidents is implemented through the following activities:

- Preparing a rehabilitation plan that includes:

* start of rehabilitation to be taken at the moment when the uncontrolled flow of accidents definitely stops (extinguishing the fire, stopping the release or dispersion of toxic gases/ liquids and eliminating the danger of further explosions), the field,

* a decision on the repair by the Ministry to withdraw a team from

* a detailed description of the measures and procedures, drafted in accordance with the Law on Environmental Protection. 
- The field work which includes:

* rehabilitation activities,

* maintaining a constant connection with the ministry, depending on a degree of rehabilitation.

- The accident report which has:

* analysis of the causes and consequences of accidents,

* development and course of incidents and responses to accidents,

* assessment of the size of an accident,

* analysis of the current situation,

* proposed measures for the rehabilitation, etc.

\section{Proposed models}

Although the concept of the entire response system in Serbia (the proposal presented in Figure 2) is not legally constituted as a whole, almost all elements of the above systems are in place with experienced personnel. The existence of specialized teams under the jurisdiction of the Ministry of Energy, Development and Environmental Protection and the Ministry of Defence should be emphasized in particular. These teams are made up entirely of professionals, specially trained personnel.

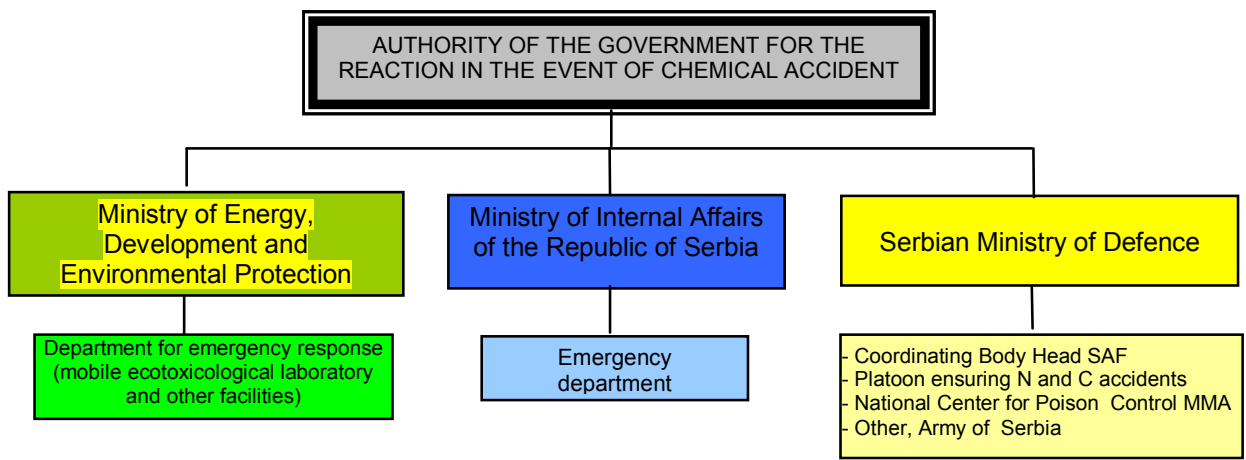

Figure 2 - Proposed model of the System of the Republic of Serbia for the reaction in case of chemical accidents

Slika 2 - Predlog modela Sistema Republike Srbije za reagovanje u slučaju hemijskog udesa

The proposal of the management in case of accidents should operate in accordance figure 3 . However, current legislation does not define the binding moments in the system [2]. 


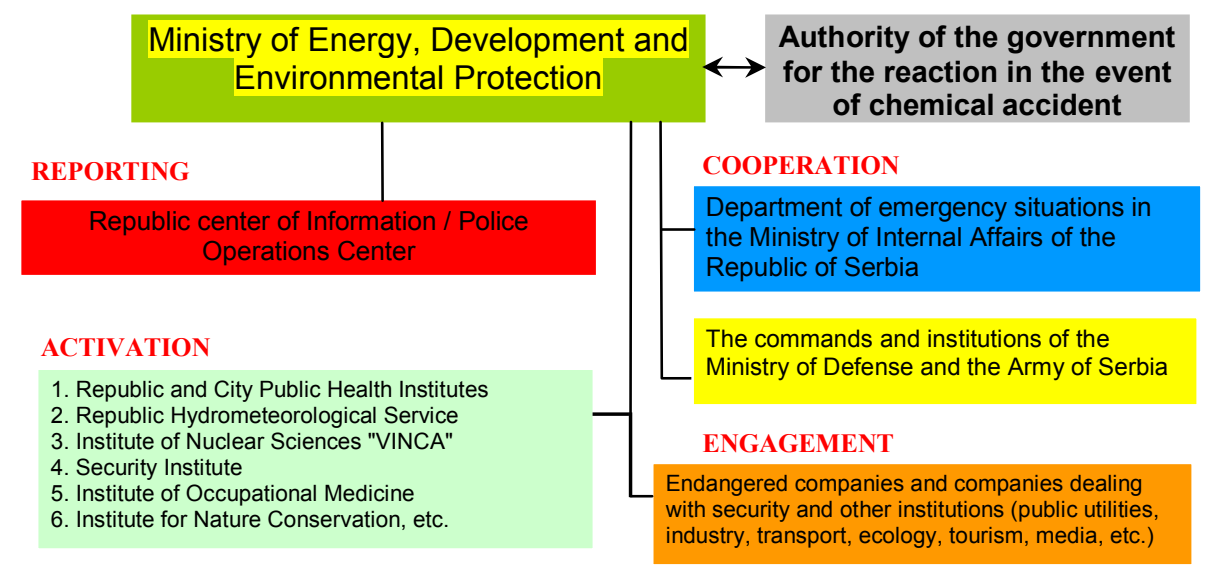

Figure 3 - Management system in case of chemical accidents Slika 3 - Sistem upravljanja u slučaju hemijskog udesa

Depending on the volume of chemical accidents, municipalities and counties would have their own teams for assessment and alarming at the local level. On the other hand, since it would have to be informed about the dangers of any scale, the government body would also carry out its assessment of the need for the involvement of specialized institutions, teams and agencies.

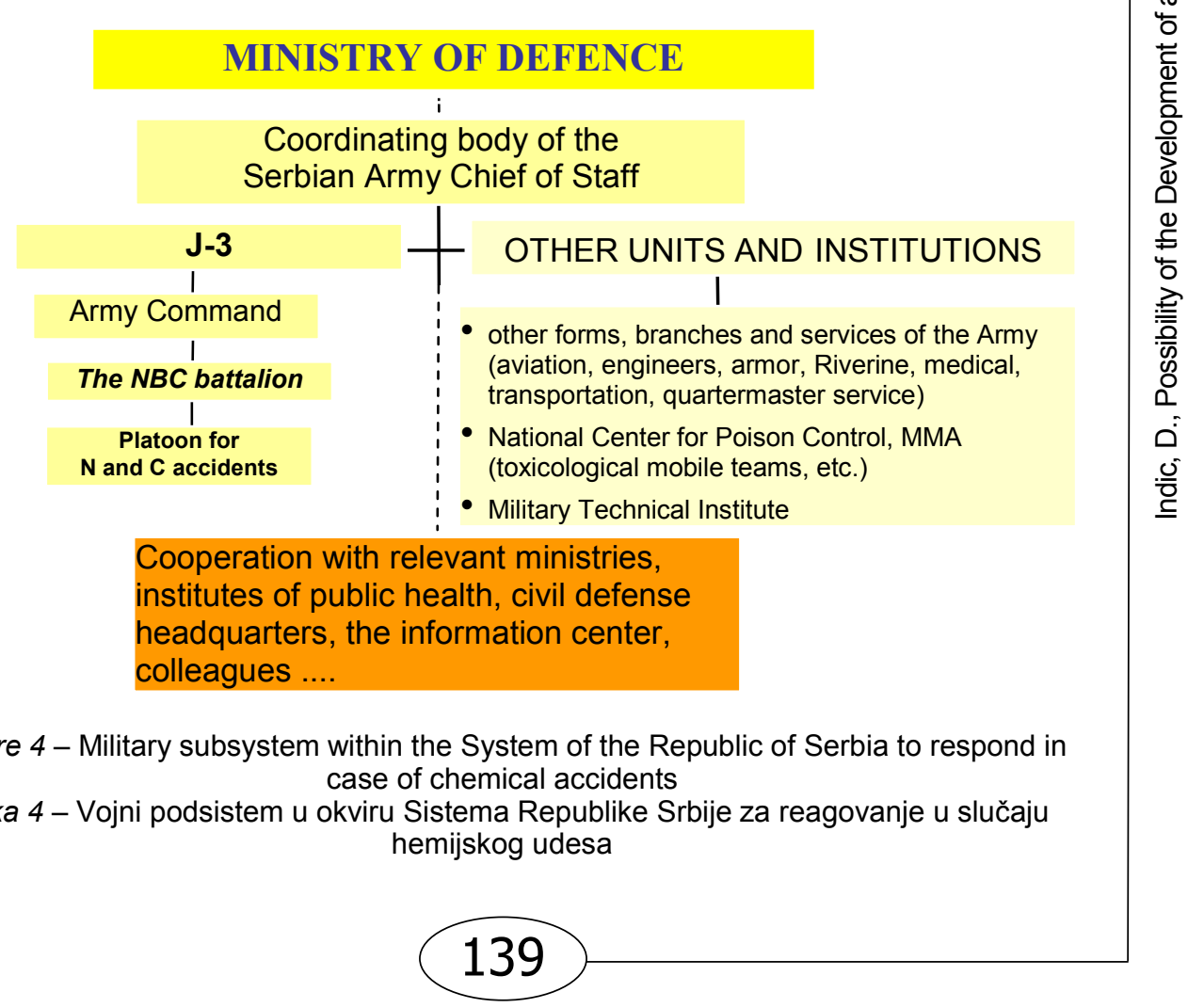


A fully functional, specialized part of the response - the military subsystem - is shown in Figure 4. A coordinating body was formed back in 1998 at the level of Chief of Staff of the Army of Serbia, responsible for organizing and coordinating the military security in case of nuclear and chemical accidents in peace.

It also made other versions of guidelines for the provision of the Serbian Army against nuclear and chemical accidents in peace, as well as training programs for special forces engaged in eliminating the consequences of accidents $[7,8]$.

As in any system, improvements are possible, such as improving the structure of command in the Serbian Army, as shown in Figure 5. It is evident that each level of command of a garrison - airport has an appropriate team, while the operational level of command and the General Staff of the Army of Serbia organize teams and an appropriate coordination body for the management in case of accidents.

A structure similar to some extent had to be up to the level of districts/municipalities in civil structures, and special organizations at the level of major cities.

\section{Managing the security of the Army Nuclear and Chemical}
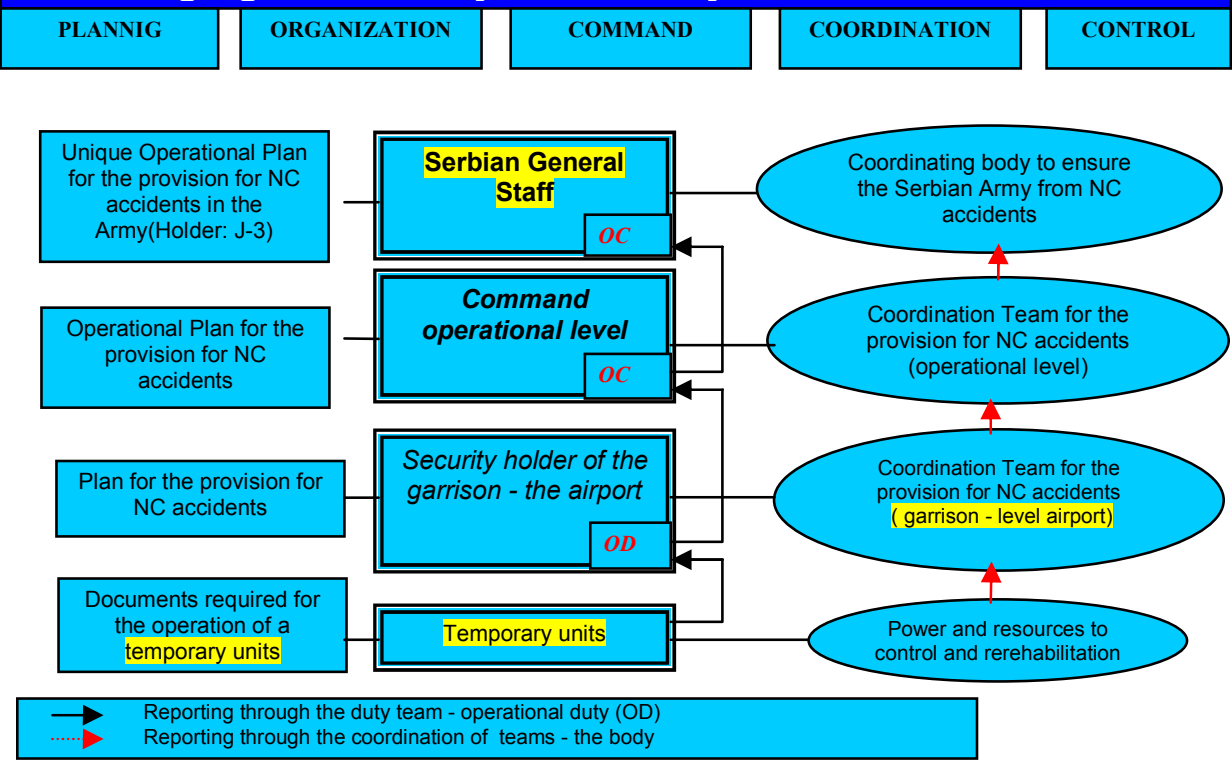

Figure 5 - Showing leadership by providing the Serbian Army for nuclear and chemical accidents

Slika 5 - Prikaz rukovodjenja obezbeđenjem Vojske Srbije od nuklearnih i hemijskih udesa 


\section{Serbia opportunities for cooperation in the field of protection and assistance}

In accordance with Article $X$ of the Convention on the Prohibition of Chemical Weapons, each member state has the right to seek assistance in case of danger from the use of chemical weapons or for the development of a national system of protection and response in case of chemical hazards. Also, each country is obliged to OPCW to offer one of the following types of contributions [1]:

- Monetary donation,

- Unused amounts of NBC and other protective equipment,

- Adequate human resources (experts, teams, units), or specific services (expertise, estimates, projects, manuals and instructions, training, assistance in responding, etc.) that the OPCW can use in case another Member State needs assistance.

The institutions and the team of Serbia, which may be declared for the provision of assistance under the call of the OPCW are as follows:

- Centre for staff NBC training;

- The security platoon for nuclear and chemical accidents;

- Military Technical Institute;

- The National Poison Control Centre, Military Medical Academy;

- Mobile ecotoxicological laboratory (under the relevant ministries).

\section{Centre for staff NBC training}

The centre operates as a training institution for officers, NCOs and civilians of the Army of Serbia and other countries in the region regarding NBC defense issues, through the implementation of various courses such as:

- A course for the application of chemical materials for temporary incapacitation;

- Rate of detection and dosimetry of toxic chemicals;

- Course of radiological-chemical-biological decontamination, etc.

In addition, the implementation is done on OPCW courses (basic and advanced) in English, in which members are trained by foreign countries for the OPCW instructors. Some of the content to be implemented is:

- Work with a variety of modern means of NBS services;

- Implementation of laboratory exercises in the field of qualitative and quantitative analysis of highly toxic substances (HTS) and other harmful substances;

- Execution of field detection and decontamination exercises HTS and their imitators; 
- Perform a task in the field of eliminating the consequences of chemical accidents, etc.

Members of the Military Technical Institute, National Center for Poison Control, MMA and the OPCW inspectors are also included in the implementation of courses.

\section{The security platoon for nuclear and chemical accidents}

The basic characteristics of platoon are:

- Possession of modern safety equipment,

- Possession of modern equipment for the detection (semi-automatic and automatic detectors, chemical monitors, personal electronic chemical light detectors) and sampling,

- Mobile analytical laboratory (GC and colorimetric measurements in association with the Centre for staff NBC training),

- Possession of equipment for marking contaminated soil,

- Possession of modern equipment for decontamination and decontamination materials (DS-2, ED-1 emulsion, calcium hypochlorite, adsorbents, overheated steam and hot air, etc.)

- Quick readiness.

\section{Military Technical Institute}

The part of the Military Technical Institute in charge of chemical protection for laboratory possesses:

- Analysis of toxic and hazardous substances, with sections for:

- qualitative and quantitative analysis of HTS and recycling and treatment of liquid organic compounds,

- analysis of water and the effectiveness of physical-chemical treatment of water,

- examination of the efficacity of HTS degradation and testing for the detection of toxic substances;

- NBC protection, with sections for:

- Testing of full body protection, testing and characterization of plant protection respiratory organs [9].

\section{The National Poison Control Centre,} Military Medical Academy

The main tasks are [10]:

- Continuous updating of data on toxic and hazardous chemicals;

- Fire database production, storage and transport in the field of chemical industry (risk assessment); 
- Detection, qualitative and quantitative analysis of toxic chemicals and HTS, primarily in the tissues;

- Specialist consultation on the principles of care for acutely poisoned;

- Training of medical personnel to take proper measures and procedures in the treatment of acutely poisoned;

- Education of the population in the area of personal protection;

- Cell toxicological engagement team.

\section{Mobile ecotoxicological laboratory}

The basic features of the Mobile ecotoxicological laboratory are:

- Constant readiness of professional teams in the event of an accident;

- Monitoring of air pollutants, water and soil and sampling;

- Qualitative and quantitative analysis of toxic industrial materials;

- Constant upgrading of equipment and analytical database of toxic substances;

- Regional (district) principle of organization of teams.

\section{Conclusion}

The necessary measures for an effective response system in case of chemical accidents could be determined by:

- Formation / activation of the appropriate government authorities to act in case of chemical hazards.

- Improving organizational schemes of action in case of chemical accidents.

- Modernizing the legal framework of the system to respond in case of chemical accidents in line with European standards, norms and recommendations.

- Fire Training and continuous chemical databases on production, storage and transport.

- Maintaining a database of toxic and harmful chemicals.

- Continuous upgrading of manuals and guidelines for responding in case of chemical accidents at all levels.

- Preparation of updating the risk management methodology tailored to the specific accident characteristics of the territory of the Republic of Serbia.

- Development of appropriate plans for the protection from accidents (preventive measures, training, notification system) for each part of the territory where accidents might occur. [11]

- Establishing and equipping permanent and emergency teams on call, with different tasks in the response to chemical accidents (risk assessment, propose measures and implementation of rehabilitation measures). 
Activation and equipping regional and local centers to notify the police forces of the Republic of Serbia.

- With adequate equipment modernization, the Republic of Serbia has significant potential to offer:

- Unit,

- Experts and expert teams,

- Mobile laboratories, and

- Training centers.

\section{References:}

[1] Convention on the Prohibition of the Development, Production, Stockpiling and Use of Chemical Weapons and on their Destruction (Chemical Weapons Convention) http://www.opcw.org/chemical-weapons-convention, 27. 10. 2011.

[2] Šimurina, M., Krstić, B. Summary of activities in case of accident during transportation of hazardous materials, Proceedings of: "Dangerous goods manufacturing, storage, transport and use", Preving ad. Beograd, 2003, page 273-281.

[3] Cekovic, B., Šutulović, LJ., Protection Program. System response in case of chemical accidents (proposed model). Serbia and Montenegro, Symposium: Managing the risk of chemical accidents - Proceedings, Belgrade, 3-7. November, 2003., page 39-47.

[4] APPELL (Awareness and Preparedness for Emergencies at Local Level) Handbook for Emergency Response, UNEP, 2005.

[5] Luković, Z., Milenkovic, Z., G. Marinkovic, Temporary Instruction for Assessment and prognosis of the situation in chemical accidents involving hazardous substances and the effects of the objects that contain hazardous materials, SMAF General Staff, Military Publishing Institute, Belgrade, 2004.

[6] Regulation on the methodology for assessing risk of chemical accidents and environmental pollution, preparation measures and measures for elimination of consequences, Official Gazette of the Republic of Serbia, No. 60, Belgrade, 1994.

[7] Guidelines for the provision of the Serbian Army of nuclear and chemical accidents in peace - temporarily, the General Staff of the Army of Serbia, Belgrade, 2008.

[8] Training curriculum of commands, units and temporary structure for providing the Army with nuclear and chemical accidents in peacetime, NBC Management, Belgrade, 1998.

[9] Rajic, D., The method of compatibility means of personal NBC protection, Military Technical Bulletin, Vol.57, No.3, pp 43-57, ISSN 0042-8469, UDC $623+355$ / 359, Belgrade, 2009.

[10] Joksović, D. Presentation of the National Poison Control Center-care organization in chemical accidents and disasters, Belgrade, 2005.

[11] Biocanin, R., Chemical accidents and risk assessment, Military Technical Bulletin, vol. 52, no. 5, pp.534-541, ISSN 0042-8469, UDC $623+355$ / 359, Belgrade, 2004. 
MOGUĆNOSTI REPUBLIKE SRBIJE U RAZVOJU SISTEMA ZAŠTITE OD HEMIJSKIH UDESA

OBLAST: hemijske tehnologije

VRSTA ČLANKA: stručni članak

Rezime:

U skladu sa važećom zakonskom regulativom po pitanju zaštite životne sredine, strukture i postojećih elemenata sistema za reagovanje $u$ slučaju hemijskog udesa, radovima drugih saradnika koji se bave navedenom problematikom i perspektivama koje su planirali nadležni i odgovorni za očuvanje životne sredine, u radu je prikazan predlog modela sistema za reagovanje u slučaju hemijskog udesa. Razmatrane su mogućnosti različitih institucija i ustanova Republike Srbije specijalizovanih za angažovanje u postupcima saradnje $i$ zaštite od hemijske opasnosti, a u skladu sa članom X Konvencije o zabrani hemijskog oružja.

Uvod

Težeći ka evropskim integracijama Republika Srbija poklanja sve više pažnje zaštiti životne sredine, a kao jedan od važnih segmenata izdvaja se sistem za reagovanje u slučaju hemijskih udesa. Kako je ova oblast još uvek nepotpuno regulisana neophodno je da se formira jedinstveni organ vlade koji bi koordinirao rad već postojećih institucija u okviru različitih ministarstava Republike Srbije.

Unapređenje mera zaštite

Unapređenje mera zaštite može se postići kroz: usklađivanje pravne regulative iz ove oblasti sa evropskim standardima, stalno ažuriranje baza podataka o toksičnim materijama i njihovom skladištenju, osavremenjavanje i izradu literature i obezbeđivanje adekvatne opreme za rad specijalizovanih ekipa.

Razvoj sistema Republike Srbije za reagovanje u kriznim situacijama

Razvoj ovog sistema trebalo bi da se odvija kroz razvoj informacionog sistema, unapređenje sistema upravljanja u situacijama hemijske opasnosti, razvoj i opremanje mobilnih ekotoksikoloških laboratorija i dr.

Povećanje sposobnosti Republike Srbije za rad na projektima u zaštitne svrhe

Upravljanje rizikom od hemijskih udesa je veoma složena aktivnost, a može se prikazati kroz četiri faze: prevenciju, pripravnost, reagovanje i otklanjanje posledica. Neka od navedenih faza neće se realizovati ukoliko je prethodnom potpuno otklonjena opasnost. Pošto u Republici Srbiji nije u potpunosti konstituisan sistem za reagovanje u slučaju hemijskih udesa, u radu je prikazan predlog njegovog modela. 
Osnova predloga sastoji se u tome da se na najvišem nivou (npr. u Vladi RS) formira organ koji će upravljati navedenim sistemom i koordinirati rad svih angažovanih snaga. Primer unapređenja organizacije obezbeđenja od hemijskih udesa dat je kroz prikaz obezbeđenja koji funkcioniše u Vojsci Srbije. Republika Srbija može za potrebe međunarodnih organizacija koje se bave ovim problemom angažovati deo svojih kapaciteta među kojima se izdvajaju: Centar za usavršavanje kadrova $A B H O$, vod za obezbeđenje od nuklearnih i hemijskih udesa, Vojnotehnički institut, Nacionalni centar za kontrolu trovanja VMA i mobilne ekotoksikološke laboratorije.

\section{Zaključak}

Predloženi model za reagovanje u slučaju hemijskih udesa podrazumeva formiranje upravljačkog organa i njegov puni doprinos na uspešnom objedinjavanju rada svih učesnika u ovako složenom sistemu. Naravno, sve to mora pratiti osavremenjavanje pravne regulative iz ove oblasti, stalno ažuriranje baza podataka o toksičnim materijama i načinu njihovog korišćenja $i$ čuvanja, izrada odgovarajućih planova zaštite od udesa i formiranje i opremanje interventnih timova za reagovanje na hemijski udes.

Ključne reči: hemijski udes, reagovanje, zaštita.

Datum prijema članka/Paper received on: 28. 12. 2011.

Datum dostavljanja ispravki rukopisa/Manuscript corrections submitted on: 30. 01. 2012.

Datum konačnog prihvatanja članka za objavljivanje/ Paper accepted for publishing on: 01. 02. 2012. 